\title{
The Naming Process Among the Lamba People of Zambia: A Socio-cultural Study
}

\author{
Gerald Chishiba
}

Department of Languages and Literature, School of Humanities and Social Sciences, The University of Zambia, Lusaka, Zambia

\section{Email address:}

geraldchishishiba@yahoo.co.uk

\section{To cite this article:}

Gerald Chishiba. The Naming Process Among the Lamba People of Zambia: A Socio-cultural Study. International Journal of Education, Culture and Society. Vol. 2, No. 3, 2017, pp. 83-87. doi: 10.11648/j.ijecs.20170203.11

Received: February 14, 2017; Accepted: March 16, 2017; Published: April 4, 2017

\begin{abstract}
This article discusses the issue of naming children, youths and adults among the Lamba People of the Copperbelt Province in Zambia and the significance of the names given to either children or adults. My study looks at a number of areas in the naming process. Firstly, the study discusses the naming process that follows the birth of a child. Secondly, it examines the phenomenon of changing names, in some cases, when a child has reached the age of 10-12 years. In addition, this study gives the readers some examples of adults who also adopted new names in adulthood, thereby despising the earlier names given to them by the elders of their community. Apart from the naming process, this study also looks at different categories of names found among the Lamba People of the Copperbelt Province. Lamba names can broadly be classified under two categories. The first type concerns names that arise from the circumstances surrounding the birth of a child. The second type is about names emanating from the socio-psychological environment.
\end{abstract}

Keywords: Naming Process, Spirit Name, Ilamba (Lamba Land), Lamba People

\section{Introduction}

The Lamba People are generally found in a territory called "Ilamba" or Lamba land. This territory is mainly found on the Copperbelt Province of Zambia which before Independence was called Northern Rhodesia. Zambia is situated in Southern Africa and it shares borders with eight (8) neighbours, namely: Zimbabwe to the South, Botswana and Namibia to the South West, Mozambique to the South East, Angola to the West, and Malawi to the East, the Democratic Republic of Congo to the North and North West and Tanzania to the North East. Zambia has more than 73languages/ethnic groups (Kashoki, 1990). There are also some Lambas on the other side of the border in the Katanga Province of the Democratic Republic of Congo. This article focuses on the naming of children among the Lamba people found on the Copperbelt Province of Zambia. This article has been divided into four parts. The first part gives a panoramic view of the linguistic/ethnic situation of Zambia. The second one looks at the actual naming process among the Lambas of the Copperbelt Province in Zambia. The third part concentrates on the different categories of names and their meanings. The fourth part focuses on the names and meanings of the Lamba clans that the chiefs on the Copperbelt belong to. As professor Mukumbuta indicates in his encyclopaedia of Zambian names, published posthumously and edited by Chanda Penda (2013), the Lamba People have maintained their culture and tradition despite the fact that they dwell in a province that is highly urbanised. The names given to a child at birth or later in his life tend to cling to them all the days of their pilgrimage on Earth. I should add that, as far as I know, this study is the first of its kind as personal naming among the Lamba People has never been explored in depth before.

\section{Methodology}

The approach followed in this research work is purely qualitative. I wanted to find out whether Lamba names carry any meaning and how these given names are arrived at. To achieve my objectives, I relied on two sources of information. To start with I looked at the brief account of Professor Clement Doke (1931) concerning names among the Lambas of the Copperbelt Province in Zambia. Secondly, I selected a number of Lamba traditional Chiefs, Chieftainesses and elders who were then interviewed. I wish to indicate that the bulk of the data I collected was obtained 
from interviewing these informants.

\section{Findings and Discussion}

\subsection{Language Groups in Zambia}

As indicated by Chimuka (1977), the following languages/ethnic groups are found in Zambia today: Nyika, Sala, Seba, Senga, Shanjo, Shila, Simaa, Soli, Subiya, Swaka, Tabwa, Twa, Unga, Wandya, Yombe, Luunda, Luvale, Makoma, Mambwe, Mashasha, Mashi, Mbowe, Mbukushi, Mbumi, Mbunda, Mbwela, Mukulu, Mulonga, Namwanga, Ndembu, Ng'ambo, Nkoya, Nsenga, Nyengo, Afrikaans, Ambo, Aushi, Bisa, Bemba, Luchazi, Lumbu, Lunda, Lundwe, Lungu, Chewa, Chikunda, Chishinga, Cokwe, English, Gova, Ila, Namwanga, Iwa, Kabende, Kaonde, Kosa, Kundai, Kwandi, Kwandu, Kwangwa, Lala, Lenje, Lima, Liyuwa, Lozi, Luano and Lamba, the focus of my study. Lamba belongs to the Bemba-Lamba-Lala linguistic grouping, meaning that some names found among the Lamba people can also be found among the Lalas as well as the Bembas.

\subsection{Lamba Naming Process}

According to Clement Doke (1931), the naming process in Lamba Land (Ilamba) can be divided into three distinct stages, the first stage concerns the naming of children at birth, the second stage relates to the adoption of new names in early adolescence between 10 and 12 years, while the third and final stage refers to the changing of names in adulthood through baptism or any other special circumstance.

The naming of a child among the Lamba people of the Copperbelt Province in Zambia takes place as soon as the child is born and after the navel has been cut and the new born baby has been washed in warm water by a midwife. The naming of a newly born baby is the responsibility of a chosen elder in the family. The name given to the new born baby is usually a name taken from one of the deceased relatives and it is commonly referred to as the spirit name, implying that the spirit of the dead relative has been reincarnated. In other words, the dead person has come back to life to live in the body of the newly born baby. Then a name given to the child at birth may be changed at a later stage in life. It may be changed during early adolescence or during adulthood. It should be noted, however, that the changing of names is more common among boys and not girls.

Professor Clement Doke (1931) explains that when a child has reached the age bracket of 10 to 12 years, he has a possibility to choose or be given a new name to replace the spirit name which was given to him at birth. The new name can either be chosen by the child himself or it can be given by an elder member of the family such as the grandmother or maternal uncle. The new name has great significance and is closely linked to the character or personality of the child. For instance, when a child has opted to be named "Ntembeni", it would imply that the child can fight many people at once without any fear at all and without being defeated. Similarly, a child may choose to be called Kaputulamilandu, meaning that he is a problem solver where other people have failed. There are also other names, such as Tayabunga or Nsandabunga meaning "Scatterer of Gun Powder" and the list goes on. According to Clement Doke (1931), the changing of names can be motivated by two things. Firstly, there are names that are motivated by self-praise such as, Ntambika (the one that generously offers food); "Kanyankula" (the one who kills at one shot). Secondly, there are names connoting self-pity such as Chipeso (sleeping Mat), Chilupulamatipa (Mud-treader) and also called Chilupula, Mbulawabo or "Kipasu" meaning that one of a set of twins has died.

Furthermore, there is also a possibility among the Lamba people of the Copperbelt Province of Zambia to change their names in adulthood and adopt a new one. With the advent of colonialism and Christianity, A lot of western names were introduced, mainly under the influence of Christianity. According to Professor Mukumbuta Lisimba (2013), two categories of names can clearly be identified among all Zambian tribes or ethnic groups, and the Lamba people are no exception. The first category involves names that arise from the circumstances of birth, while the second one consists of names that arise from socio-psychological environment.

\subsection{Names Arising from Circumstances Surrounding a Child's Birth}

Below is a list of names given to newly born children on the basis of the circumstances surrounding their birth and what the name actually means.

1) Mushinga: is a name given to a child who is surrounded by the umbilical cord at birth.

2) Chishalamunda: is given to a child whose father died before the birth of the child.

3) Mushala or Malekano: is given to a child whose mother died during delivery.

4) Kalomba: is given to a child who, during the process of being born, pushes one of his hands first as he tries to come out.

5) Mashuko or Luse: is given to a child who looks very tired at birth, such that he cannot even cry. He is only revived later by the midwife.

6) Mapensho or Machushi: is a name given to a child whose mother was very sick before his birth.

7) Milemyo: is given to a child whose mother nearly died during child birth, and the name means, 'let us praise God for saving the mother'.

8) Katwishi: is given to a child whose child birth was characterised by complications on the mother's part.

9) Mbiko: is given to a child whose mother is, for the second time, experiencing complications while giving birth.

10) Mulombwa or Mabula: is given to a child at birth when the parents had to consult diviners or traditional medicine providers for the mother to conceive.

11) Cholamabula: is the one who follows Mabula, or the 
one who is born immediately after Mabula from the same mother.

12) Sula: is the name given to a child whose mother was neglected or abandoned by her husband, before and after its birth.

13) Kabishi: is a Lamba name for a premature baby that has to go through a traditional or modern day incubator.

14) Chakwangasha or Mambepa: is given to the surviving child after many other children from the same mother have been dying. Consequently, the parents are not sure whether this one would survive or pass on like the others.

15) Katapa: (Cassava leaves), is the name given to a child whose parents suspect the child will be killed by witches or wizards for relish.

16) Nkulilepi or Kalekeni: a name given to a child by parents who have been losing children one after the other. This time around the parents are pleading that their enemies should spare his life and let this child live.

17) Chamuchani: is a name given to a child born in the bush while the mother was being taken to the nearest health post or hospital.

18) Chamumbalasa: is given to a child born in the shelter outside the main house, because the main house is overcrowded and there is no privacy.

19) Ulunyena: is a name given to a child who defecates immediately after birth.

20) Mwika: is given to a child whose leg comes out first during delivery.

21) Chikuto: is a name given to a child who is born with the placenta.

22) Akapopo or Akafunga: is the name given to a still born child. Such a child is buried secretly in the bush by the midwife and another elderly woman.

23) Akasenshibeba: is given to a child who is born with teeth. Such a child is, according to the Lamba tradition, to be a carrier of bad luck-it is a bad omen and hence should not be allowed to live.

24) Bampundu: is the name given to twins when both are of the same sex.

25) Amapasa: refers to twins who are not of the same sex.

26) Umwanawamushike: is the name given to an illegitimate child whose mother got pregnant outside wedlock.

27) Umwanawamankunamwa: is the name given to a child who has cut the upper teeth first instead of the lower ones.

As observed by Clement Doke (1931), such a child is considered to be a wizard, who should not be allowed to live, and consequently, such a child was thrown into a pool and the parents of such a child were not allowed to mourn. It was strictly forbidden.

a) Chite: refers to a child who does not walk within the normal expected period. b) Chamushalila: was given to a surviving older member of the family upon whom all the responsibilities fell following the death of his peers in the family.

\subsection{Names Emanating from the Socio-psychological Environment}

The Lamba people are easily identifiable through the name of their clan, or through their clan association or membership. Every lamba person belongs to a clan (umukoka-singular) (Doke, 1931:193-194). Below are the names of the 32 clans (imikokaplural) found in Lambaland and as you can see, these are compound words consisting of a prefix "abena" (meaning belonging to or a member of) plus the referent, the object or thing being referred to.

1) Abenampumpi: this name refers to the people who belong to the wild dog clan.

2) Abenakalungu: the people belonging to the bead clan.

3) Abenakashimu or Abalembo: the people belonging to the bee clan.

4) Abenamusamba or Abashishi: the people who belong to the rope/bark clan.

5) Abenamumba: people belonging to the clay clan.

6) Abenabesa: people belonging to the plain clan.

7) Abenamfula: people belonging to the rain clan.

8) Abenachela or Abenambulo: people belonging to the metal clan.

9) Abenakaloba: people belonging to the soil clan.

10) Abenankalamu: people belonging to the lion clan.

11) Abenachulu: people belonging to the anthill clan.

12) Abenanswi or Abalonga: people belonging to the fishing clan/the running stream clan.

13) Abenaluwo: people belonging to the wind clan.

14) Abenamulilo: people belonging to the fire clan.

15) Abenakani: people belonging to the grass clan.

16) Abenabowa: people belonging to the mushroom clan.

17) Abenamaila: people belonging to the sorghum clan.

18) Abenangulube: people belonging to the river clan.

19) Abenanguni: people belonging to the honey guide clan.

20) Abenankulimba: people belonging to the pigeon clan.

21) Abenambwa: people belonging to the dog clan.

22) Abenasanje: people belonging to the blue monkey clan.

23) Abenakabundi: people belonging to the galago clan

24) Abenansoka: people belonging to the snake clan.

25) Abenamishishi: people belonging to the human hair clan.

26) Abenambushi: people belonging to the goat clan.

27) Abenatembo: people belonging to the wasp clan.

28) Abenang'anga :people belonging to the herbalist clan.

29) Abenambeba: people belonging to the mouse clan.

30) Abenanyendwa: people belonging to the female private parts clan.

31) Abenansofu: people belonging to the elephant clan.

32) Abenang'andu: people belonging to the crocodile clan. 


\subsection{Names Arising from Colonial and Modern Civilisation Influence}

The naming process in Lamba is what the linguistics scholars would call nativisation or transliteration. According to Alo (1998), cited by Mutunda (2015), Transliteration is defined as "the process whereby the units of one language, e.g. words, structures, are replaced by those in another". In the same vein, Michael Onwuemene, also cited by Mutunda (2015), further defines transliteration as "the act of thinking and conceiving in one's first language and expressing the substance thought conceived in one's second language such that the second language expressions used contain some salient linguistic and rhetorical implants from the first language". In short, Nativisation or Transliteration is a process where a word is borrowed from English and given a new form that fits the recipient's orthographic norms. In other words, their phonology has been adapted to reflect the phonological system of the borrowing language. This strategy is very common among the Lambas of the Copperbelt Province in Zambia. Below is a list of such names:

1) Fifitini: from the English word 'fifteen'.

2) Kofi: from the English word 'Coffee'.

3) Tebulo: from the English word 'Table'.

4) Kabati: from the English word 'cupboard'.

5) Sande: from the English word 'Sunday'.

6) Mande: from the English word 'Monday'.

7) Nsokoshi: from the English word 'Socks'

8) Nsapato: from the Portuguese word "Sapatos"

9) Ndimanshi: from the French word "Dimanche" (Sunday)

10) Fulaulo: from the English word 'Flower'.

11) Sabata: from the English word 'Sabbath'

12) Foloko: from the English word 'Fork'.

13) Supuni: from the English word 'Spoon'.

14) Meleki: from the English word 'Milk'.

15) Kabiki: from the English word 'Cabbage'.

16) Smati: from the English word 'Smart'

17) Shitolo: from the English word Store'.

18) Elingi: from the English word erring one.

19) Pensulo: from the English word 'Pencil'.

Some scholars argue that the Lamba people have nativised these foreign words because they came into contact with the foreigners and foreign language earlier than most of the other Zambian tribes as they took up such jobs as garden boys, cooks, and so on.

\subsection{Names Emanating from the Bible}

1) Omega: from the Bible word Omega

2) Anashi: from the Bible word Ananias.

3) Mako: from the Bible word Mark

4) Luka: from the Bible word Luke

5) Kefashi: from Cephas

6) Andele: from Andrew

7) Kilioni: from Gideon

8) Eliashi: from the Bible word Elias
9) Jelemiya: from the Bible word Jeremiah

10) Eshikeli: from the Bible word Ezekiel

11) Pilati: from the Bible word Pilatus

12) Nayumi: from the Bible word Naomi

13) Lufi: from the Bible word Ruth

14) Maliya: from the Bible word Mary

15) Yakobi: from the Bible word Jacob

16) Sakaliya: from the Bible word Zechariah

\subsection{The Names and Meanings of the Clans that Lamba Chiefs Belong to}

There are 15 Lamba chiefs and Chieftainesses on the Copperbelt Province of Zambia, and each one of them belongs to a specific clan. We can subdivide these Chiefs and Chieftainesses into three categories. The first category consists of six (6) Chiefs who belong to the clan of Abenamishishi, the human hair clan. The second category encompasses seven (7) Chiefs who belong to the clan of Abena Nyendwa, the female private part clan. The remaining two (2) Chiefs belong to two different clans named after animals, one belongs to the clan of Abenansoka, the snake clan; and the other belongs to the clan of Abenambwa, the dog clan.

The following six (6) Lamba Chiefs belong to the clan of Abenamishishi, the human hair clan:

1) Chief Mushili of Masaiti District. The name Mushili means "soil" and it refers to a vast piece of land that is seemingly endless and therefore inexhaustible.

2) Chief Nkambo of Masaiti District

3) Chief Nkana of Lufwanyama District

4) Chief Shibuchinga of Lufwanyama District

5) Chieftainess Shimukunami of Lufwanyama District

6) Chief Mukutuma of Lufwanyama District

7) The following seven (7) Lamba Chiefs belong to the clan of Abenanyendwa, the female private parts clan.

8) Chief Lumpuma of Lufwanyama District

9) Chieftainess Lesa of Mpongwe District

10) Chief Ndubeni of Mpongwe District. Professor Mukumbuta (2013)explains that Ndubeni is a name given to a person who had gone away, and upon his return, his people failed to recognise him. But he insisted that he was indeed the person they all knew.

11) Chief Fungulwe of Lufwanyama District

12) Chieftainess Malembeka of Mpongwe District.

13) Chief Kalunkumya of Mpongwe District

14) Chief Mwinuna of Mpongwe District. According to a Lamba native in formant, the name Mwinuna refers to a person who puts things right, a person who rectifies mistakes earlier committed.

15) The other two (2) Lamba chiefs who do not belong to any of the clans mentioned above are:

16) Chief Machiya of Mpongwe District, who belongs to the clan of Abenansoka (the snake clan)

17) Chief Chiwala of Masaiti District who belongs to the clan of Abenambwa (the dog clan) 


\section{Conclusion}

Names are very important among the Lamba People on the Copperbelt Province of Zambia. Unlike the western World, the Lamba do not name their children arbitrarily. Names are often given because of the cultural meaning they convey. We have seen from the fore going that names are given for various reasons. Some names emanate from the circumstances that surrounded the birth of a child, while others are closely related to the socio-psychological environment. Generally speaking, names are given as soon as a child is born. However, a child can opt to change his name when he is about 10 to12 years old, or during adulthood.

\section{References}

[1] Akinnaso, F.N. (1980). The Socio-linguistic basis of the Yoruba Personal Names. Anthropological Linguistics 22(6)275-303.

[2] Crane, L. (1982). African names: People and Places. UrbanaChampaign, University of Illinois.

[3] Chimuka S. S. (1977). Zambian Languages: Orthography approved by the Ministry of Education, National Educational Company of Zambia (NECZAM).
[4] Doke C. (1931). The Lambas of Northern Rhodesia. George G. Harraps \& Company Ltd. London.

[5] Kashoki M. (1989). Language in Zambia; The last Battle in the Frontline (Seminar Paper).

[6] Kashoki M. (1990). The Factor of Language in Zambia. Educational Publishing House, Lusaka, Zambia.

[7] Mukumbuta L. (2000). Lozi Names in Language and Culture, Libreville: International Centre for Bantu Civilisations.

[8] Mukumbuta L. (2013) (posthumously). Encyclopaedia of Zambian Names, edited by Chanda Penda and Published by Pensulo Publishers Series.

[9] Mutunda S. (2011). Personal names in Lunda Cultural Milieu in The International Journal of Innovative Interdisciplinary Research. Issue 1, December, 2011.

[10] Mutunda S. (2015). Linguistic Innovation in Zambia Literary Text. The example of Malama Katulwende's Bitterness.

[11] Tembo M. S. (2006). Zambian Traditional Names, Lusaka, Julubi Enterprises Ltd.

[12] Mohome P. M. (1972). Naming in Sesotho: Its Socio-Cultural and Linguistic Basis. Names 20:3, New York University College. 